\title{
Considering the IDD Within the EU Legal Framework on ADR Systems
}

\author{
Flaminia Montemaggiori
}

\section{Introduction}

The favour towards alternative dispute resolution (ADR) methods arose in the United States in the mid-seventies to underline, in the face of the crisis of access to justice, the need to use tools other than judicial measures to ensure consumer protection and to decongest the judicial system. ${ }^{1}$ Since then, these mechanisms have also spread throughout the EU, including a heterogeneous range of methods and procedures, such as mediation, various forms of arbitration, Ombudsman, etc.

Directive 2016/97/EU of 20 January 2016 on insurance distribution (IDD) also provides for the establishment of adequate out-of-court complaint and redress procedures for the settlement of disputes between customers and insurance distributors. The directive is therefore added to the other sectoral directives of the financial system aimed at ensuring the establishment of adequate ADR procedures for disputes concerning banking and financial services.

In this sense, the IDD represents the last step, in a chronological sense, of the growing attention of EU institutions towards out-of-court procedures, deemed as appropriate and effective tools to ensure better access to justice especially for consumer disputes.

Alongside the sectoral directives laying down the obligation for Member States to implement such systems, there are other European legislative measures of a crosscutting nature, as they aim to define the basic principles of ADR procedures:

Opinions expressed are views of the author.

${ }^{1}$ Sander (1976), p. 111 ss. More details in paragraph 2.

F. Montemaggiori $(\bowtie)$

IVASS (Italian Supervisory Authority for Insurance Sector), Insurance Ombudsman's

Technical Secretariat, Rome, Italy

e-mail: flaminia.montemaggiori@ivass.it 
reference is made to Commission Recommendations 98/257/EC and 2001/310/EC, the 2002 Green Paper, the harmonisation of Consumer ADR systems pursued by Directive 2013/11/EU and the regulation of mediation laid down by Directive 2008/ 52/EC.

In addition to regulatory actions, a number of networks aimed at facilitating the resolution of transnational disputes and promoting cooperation between ADR entities have been launched at European level, such as the ECC-Net for consumers ${ }^{2}$ and the Fin-Net concerning financial services disputes. ${ }^{3}$

By means of legislative measures and networks of organisations, consumers will therefore have, at least abstractly, the tools to be able to obtain effective and low-cost protection of their rights, especially in the case of small claims for which the use of a judicial solution might appear disproportionate in terms of time and costs. ${ }^{4}$

This protection is now guaranteed for the insurance sector by the IDD, which, as already mentioned, achieves full coverage by ADR procedures in all financial sectors where consumer rights are involved. Of course much will depend on the Member States' implementation of the directive, especially concerning the most characterising issues such as the subjective scope of application (which subjects will have to adhere to the system), the nature of the disputes that may be taken into account, dispute settlement procedures, sources of financing, etc.

Many choices will necessarily be influenced by the different national legal traditions and the specific purpose of public supervision of the financial sector, to which the insurance sector belongs. However, a positive effect for the insurance sector could still be expected: considering the high level of conflict between customers and insurance distributors and the burden of those disputes on legal litigations, the creation of an effective ADR system could lead to deflationary effects for judicial litigations and related costs, with potential downside effects on premiums charged to policyholders. ${ }^{5}$ It would also strengthen the relationship of trust between insurance operators and customers and consumer confidence in the financial system with a view to its soundness and stability. Finally, the "educational role" of the new body's decisions should not be underestimated: on the one hand, they could have a

\footnotetext{
${ }^{2}$ The European Consumer Centres Network (ECC-Net) provides free help and assistance in dispute resolution when the consumer and trader involved are based in two different European countries (Member States, plus Iceland and Norway), https://ec.europa.eu/info/live-work-travel-eu/con sumers/resolve-your-consumercomplaint/european-consumer-centres-network_en.

${ }^{3}$ Fin-Net is a network of national organisations responsible for out of court settling consumer complaints in the area of financial services, https://ec.europa.eu/info/business-economy-euro/bank ing-and-finance/consumer-finance-and-payments/retail-financial-services/financial-dispute-resolu tion-network-fin-net_en.

${ }^{4}$ The use of ADR methods is a question of justice policy that has important consequences for both the quality and efficiency of judicial outcomes. For more details: BEIS (2018), "Resolving consumer disputes: ADR and the court system"; ELI-ENCJ (European Network of Councils for the Judiciary) (2018), "The relationship between formal and informal justice: The courts and ADR"; EU Commission (2018a), "Capacity-building grants for ADR entities".

${ }^{5}$ In this sense the legislative decree report on the IDD implementation in Italy.
} 
preventive and dissuasive effect on similar violations, on the other hand they could be a tool for undertakings to monitor product adequacy over time.

\section{ADR Systems from the USA to the EU: Distinctive Features and Common Purpose}

ADR systems refer to a heterogeneous category of "alternative" techniques and procedures to the ordinary dispute resolution system, aimed at ensuring easy access to justice and quick and effective dispute resolution.

It is an informal justice that spread quickly in the common law countries, mainly the American system and later the English one, due to the characteristics of these legal systems, including the absence of a rigid codification of principles in which to channel any disputes. In particular, the movement that was born in the United States in the 1960s and that would then spread throughout Europe is based on the idea that the solution to the justice crisis, which was too congested, was to be found in the use of other dispute resolution measures. ${ }^{6}$

This ideology was conventionally codified at a conference held in 1976 in Minneapolis entitled "National conference on the causes of popular dissatisfaction with the administration of justice". Many speeches formulated, in the face of the discouraging situation of the judicial system, a series of proposals aimed at removing some disputes from the Courts to be redirected to other decision-making bodies outside the jurisdictional system. ${ }^{7}$ In the minds of the movement, an effective resolution of the dispute would have been achieved in terms of cost, timing and accuracy of the investigation. Access to protection would also have been guaranteed, especially for less well-off citizens who could have brought to the attention of a third party those disputes which, because of the cost of the proceedings, they would not have brought before the courts.

The transition from the cultural movement to legislative initiatives was short, with the adoption in 1980 of the Dispute Resolution Act and, in 1998, of the Alternative Dispute Resolution Act, with which ADR systems were favoured and financed by federal legislation. ${ }^{8}$ The result has been the proliferation of "customised" dispute resolution procedures in the USA, i.e. made-to-measure with respect to the dispute to be resolved. The ideology then spread to Europe, where, however, such systems have been slow to develop due to cultural resistance linked to

\footnotetext{
${ }^{6}$ The movement was linked to the ideology of a group of intellectuals, including Warren Burger (Chief Justice) and Frank Sander (Professor of Harvard Law School). See in particular Sander (1976) cit. On the topic see also: Twining (1993), p. 380 e ss; Cappelletti (1993), pp. 282-296; Della Noce (2002), p. 545.

${ }^{7}$ In particular, Sander's intervention on the "multi-door court house", in which the consumer request would no longer be filed in the court, but in a dispute resolution center which would redirect it to the most appropriate resolution mechanism. See Kessler and Finkelstein (1988), p. 577.

${ }^{8}$ Crownie (2001), p. 1768.
} 
the traditional role of the judge or due to the different experiences of other European countries on the timing of justice. Despite the diversity of forms and procedures, ADR systems appear to converge towards a fast and effective dispute resolution.

The speed is determined by the fact that these schemes use simplified procedures that can overcome the structural rigidity of the process; they are concluded in a short time and are based on affordable costs. Such systems therefore appear to be useful tools for resolving small claims against which traditional judicial instruments may not appear appropriate. The effectiveness is given by the specific competences of the decision-making bodies of ADR systems that, therefore, could be the most appropriate instrument for disputes with a high degree of technicality. Such procedures also aim to maintain or, where appropriate, restore professional and personal relations between the parties once the dispute has been resolved.

Therefore, if the objective is common, the forms in which these techniques are structured are extremely different. It is possible, however, to trace them back to two fundamental models, depending on whether they aim to define the dispute by an agreement between the parties (as mediation) or by a decision of a third party (as arbitration).

Arbitration thus constitutes the archetype of "heteronomic" ADR models, based on the knowledge and decision of the cause by a third party, having received a mandate from the parties that commit to accept that solution. The model is based on the private will that, through an agreement or an arbitration clause, establishes to refer the decision of a dispute, that has already arisen or may arise in the future, not to the judge but to qualified third impartial parties.

Mediation is a procedure in which a neutral third party, without decisionmaking power, assists the parties with conflicting interests in finding a mutually acceptable solution. The mediator therefore does not seek to impose his point of view but merely helps the parties to reach an agreement that aims to please all the contenders.

The alternatives relating to the conciliation method are more widespread, tending to compose the dispute through a solution agreed by the parties and not imposed by a third party foreign to the interests at stake. The culture of compromise has been more successful than the culture of decision, because it sets up a channel of communication between the parties who will maintain their relationship.

\section{The Main EU Regulatory Actions Regarding ADR Systems}

The interest of European institutions in ADR systems has been and is still considerable. The actions carried out over a period of 20 years are part of the European Union policies aimed at guaranteeing an area of freedom, security and justice, functional to the smooth running of the internal market and the strengthening of 
judicial cooperation..$^{9}$ A European judicial area where the protection of rights can take place not only in judicial procedures but also in alternative ways of resolving disputes. In the intention of the European legislator, alternative dispute resolution should create that virtuous circle that would lead undertakings to behave according to the standards required by the Union and consumers to purchase goods and services, confident of finding prompt protection of their rights. ${ }^{10}$

This is why ADR systems are placed in the context of policies aimed at improving access to justice: ${ }^{11}$ it happens, in fact, that this right which is normally guaranteed to citizens by the constitutional charters, ends up constituting a mere formal right, devoid of effectiveness. It would also be more appropriate to talk about instruments that are not alternative but complementary to justice, as they may sometimes be the most appropriate means for certain types of disputes and thus extend the area of protection afforded to citizens for their rights. All in order to guarantee access to justice, enshrined as a fundamental right in Article 6 of the European Convention for the Protection of Human Rights and Fundamental Freedoms-ECHR ${ }^{12}$ and enshrined as a general principle of the European law in Article 47 of the Charter of Fundamental Rights of the European Union-CFR. ${ }^{13}$

The inefficiency of the justice service could also produce serious economic consequences, as the efficiency of the processes is one of the indicators of the ease of investing in some countries of the world. ${ }^{14}$

ADR systems are therefore a political priority for European institutions, which must ensure their development and quality. The EU legislative bodies have therefore

\footnotetext{
${ }^{9}$ Article 81, par. 2, lett. g) Treaty on the Functioning of the European Union (TFEU) according to which the European Parliament and the Council adopt measures to ensure "the development of alternative methods for dispute resolution". About the EU initiatives on ADR system: Gill et al. (2017), Sirena (2018), Creutzfeldt (2013).

${ }^{10}$ The need to ensure adequate protection to consumers requires that rules conferring rights empowering consumers, when they engage in economic activities in the EU's Single Market, should be followed up by procedural rules and legislative and non-legislative tools that aim to make the enforcement of consumer rights in the Member States more effective (Report from the Commission on the application of Directive 2013/11/EU, Brussels, COM (2019) 425 final, p. 1).

${ }^{11}$ Access to justice acts as a corollary of the fundamental rights conferred by the European law: the European legislative framework cannot create rights without providing their holders with mechanisms which ensure their effective exercise.

${ }^{12}$ The ECHR is an international convention to protect human rights and political freedoms in Europe, entered into force on 3 September 1953 with the establishment of the European Court of Human Rights. Article 6 provides the right to have your case dealt with a fair and public hearing and within a reasonable time by an independent and impartial judge established by law". See more in "European Court of Human Rights, Guide on Article 6".

${ }^{13}$ The CFR enshrines political, social, and economic rights for EU citizens. It applies to the EU Institutions and its member states when implementing EU law. The right to an effective remedy and a fair trial was raised by the Court of Justice to the rank of a general principle of the European law (judgment of 15 May 1986 in Case 222/84 Johnston) and was enshrined in Article 47 of the CFR. ${ }^{14}$ World Bank ranking "World Bank doing business 2019". Other indicators are the ease of starting a business, getting a loan, the tax system, etc.
} 
progressively identified the minimum quality standards with which the different systems must comply.

A first comparative study is the Commission's 1993 Green Paper, which sets out the legal and out-of-court procedures for consumer disputes for each Member State. ${ }^{15}$ The Commission Recommendation 98/257/EC of 30 March $1998 \mathrm{~A}^{16}$ represents a milestone in the ADR theorisation process, and identifies seven principles to which the various ADR procedures must adhere: independence ${ }^{17}$ (of the decisionmaking body), transparency (of the procedure), debate between the parties, legality, ${ }^{18}$ effectiveness, ${ }^{19}$ freedom and representation. However, its scope is limited to ADR systems that envisage settlement of the dispute through the intervention of third parties who propose or impose a solution. ${ }^{20}$

European institutions' interest in ADR systems has been growing in parallel with the development of cross-border trade, in particular e-commerce, strongly linked to the degree of confidence among consumers about the effectiveness of the exercise and protection of the rights acquired. The out-of-court settlement of disputes is intended as a means of making the exercise of the right to the free movement of goods and services within the European Union effective. As citizens' exchanges and mobility intensify, cross-border disputes, often characterised by conflicts of laws and jurisdictions, are increasing.

The following Recommendation 2001/310/EC of 4 April $2001^{21}$ focuses on the principles to be followed by out-of-court procedures characterised by the intervention of a third party which facilitate the resolution of a consumer dispute by bringing the parties together and assisting them, i.e. by making informal suggestions on settlement options, in reaching a solution by common consent (recital 9). The principles are: impartiality, transparency, effectiveness and fairness. ${ }^{22}$ Therefore,

\footnotetext{
${ }^{15}$ Green Paper "Consumer access to justice and the settlement of consumer disputes within the single market, COM/93/576FINAL.

${ }^{16}$ Commission Recommendation 98/257/EC of 30 March 1998 on the principles applicable to the bodies responsible for out-of-court settlement of consumer disputes [1998] OJ L 115/31.

${ }^{17}$ It provides that where the decision is taken by an individual, the independence shall be guaranteed if the person appointed possesses the abilities required to carry out his function and if a period of office of sufficient duration is granted; when a collegiate body, the independence must be ensured by giving equal representation to consumers and professionals.

${ }^{18}$ The legality requires the decision taken by the body may not result in the consumer being deprived of the protection afforded by the mandatory provisions of the law of the State in whose territory the body is established.

${ }^{19}$ Effectiveness of the procedure is ensured through measures guaranteeing that the consumer has direct access to the procedure, free of charges or of moderate costs, only short periods elapse between the referral of a matter and the decision.

${ }^{20}$ Recital: “. . .this recommendation ..... does not concern procedures that merely involve an attempt to bring the parties together to convince them to find a solution by common consent".

${ }^{21}$ Commission Recommendation 2001/310/EC of 4 April 2001 on the principles for out-of court bodies involved in the consensual resolution of consumer disputes [2001] OJ L 109/56.

${ }^{22}$ The fairness should be safeguarded by allowing the parties to provide any necessary and relevant information, treated as confidential unless they expressly agree otherwise. (recital 15).
} 
the ADR solution may be less favourable than the result that could be achieved by the application of legal rules, without prejudice to the consumer's freedom, duly informed, to accept the proposal or not.

Several European acts were subsequently adopted to clarify specific aspects of ADR procedures with regard to the different methods that can be used. ${ }^{23}$

In 2002, the Commission renewed its interest in ADR procedures with the adoption of the Green Paper, in which the promotion of such methods is set out as a political priority for EU institutions. ${ }^{24}$ The document focused on ADR schemes in civil and commercial matters "other than arbitration" where a neutral third party handles the dispute. ${ }^{25}$

The mediation model therefore begins to assume autonomy, to then be codified in the Directive 2008/52/EC on mediation in civil and commercial disputes concerning available rights. ${ }^{26}$ This gives mediation a central role in the system of out-of-court resolution instruments in order to ensure better access to justice and contribute to the smooth running of the internal market. The Directive was therefore an important milestone in the introduction and use of mediation procedures in the EU, although its implementation differed considerably between Member States, depending on the prior existence of national mediation systems and the extent of the culture of mediation. The Directive encourages the use of mediation but also ensures a balanced relationship between mediation and judicial proceedings (Art. 1). The court may invite the parties to use mediation to settle the dispute, without prejudice to national law making the use of mediation compulsory both before and after the start of judicial proceedings. Especially in cases where recourse to mediation is mandatory, the right to an effective remedy and a fair trial, as provided for in Article 47 of the Charter of Fundamental Rights, should not be precluded. Parties to a written agreement resulting from mediation, or one of them with the explicit consent of the others, could request that the content of their agreement is made enforceable; except if the content of the agreement is contrary to the law of the Member State in

\footnotetext{
${ }^{23}$ The "Communication from the Commission of 4 April 2001 on widening consumer access to ADR", COM (2001) 161, states that the ADR procedures can be entrusted to both public and private authorities, as ombudsman, complaints committee, etc. The "European Parliament Report on action taken on the Community policy on out-of-court settlement of consumer disputes", (A5-0134-2001), stresses that at first attempts should be made to solve the dispute directly between the consumer and the traders before resorting to extra-judicial solutions.

${ }^{24}$ Green Paper on alternative dispute resolution in civil and commercial law, Brussels, 19.04.2002 COM (2002) 196 final.

${ }^{25}$ The Commission pointed out that the development of these new forms of dispute resolution had to be considered as a consensual form of social pacification more than the recourse to a judge or an arbitrator.

${ }^{26}$ Directive 2008/52/EC of the European Parliament and of the Council of 21st May 2008 on certain aspects of mediation in civil and commercial matters. See Commission report on the implementation of the directive, that shows that almost all Member States have extended the scope of their measures transposing the Directive beyond cross-border to domestic cases. See De Palo et al. (2014), Menkel-Meadow (2015).
} 
which the request is made or if that law does not provide for enforceability (recital 19).

The guarantee that consumers can refer to "quality" ADR entities for all types of contractual disputes with traders was reached by Directive 2013/11/EU on Alternative Dispute Resolution (ADR Directive). ${ }^{27}$ This is also part of European initiatives to complete the internal market; aimed at removing direct and indirect obstacles to its functioning and strengthening citizens' confidence in the means of protecting their rights.

This directive stems from the finding that, despite the Commission's recommendations of 1998 and 2001, ADR had not yet sufficiently and consistently developed in the EU. Disparities in coverage (existence of different ADR systems), in quality and knowledge of ADRs among Member States therefore represented a barrier to the internal market and were identified as one of the reasons why many consumers avoided cross-border purchases due to fearing that any disputes with undertakings could not be resolved easily, quickly and affordably. ${ }^{28}$ The absence of high-quality ADR procedures in a Member State also placed undertakings at a competitive disadvantage compared with those in other Member States, which could resolve disputes with consumers in a quicker and cheaper way. It was therefore considered necessary to achieve an harmonisation, even if minimal, of Consumer ADR systems by imposing requirements and quality standards of the procedures and bodies in charge of their management regardless of the residence of consumers within the EU.

The Directive provides for a minimum harmonisation approach, leaving wide discretion to Member States in providing for additional measures to ensure a higher level of consumer protection.

The Directive is also linked to Regulation (EU) No. 524/2013 on online disputes, entered into force on 9 January 2016 with the aim of establishing a Europe-wide online platform offering consumers and traders a single out-of-court entry point for the settlement of online disputes, through ADR entities linked to that platform. ${ }^{29}$ They are therefore two interlinked and complementary legislative instruments in the sense that only entities meeting the requirements of the Directive can be considered as ADR entities and, as such, can be registered and thus operate on the ODR platform. $^{30}$

\footnotetext{
${ }^{27}$ Directive 2013/11/EU of the European Parliament and of the Council of 21 May 2013 on alternative dispute resolution for consumer disputes. See Biard (2019), pp. 109-147; Biard (2018), pp. 171-196; Cortes (2018), pp. 82-88; Loos (2016).

${ }^{28}$ See "Study on the use of ADR in the EU of 16 October 2009", (pp. 56-63; 112.115; 120-121). As announced in the Commission's Communication 'A New Deal for Consumers' of 11 April 2018 (COM[2018] 183 final), strengthening this consumer ADR/ODR framework is a priority in the Commission's endeavour to complement the EU enforcement toolbox, make the existing enforcement tools fully effective and make EU consumer law deliver its full potential.

${ }^{29}$ Regulation (EU) n. 524/2013 of the European Parliament of the Council of 21 May 2013 on online dispute resolution for consumer disputes (Regulation on consumer ODR).

${ }^{30}$ The 'ODR platform' was launched on 15 February 2016 (http://ec.europa.eu/odr). The first report was published by the Commission on 13 December 2017 (COM 2017,744 final). About 24,000
} 
The Directive applies to national and cross-border ADR procedures. The outcome of the dispute shall be entrusted to an ADR entity, permanently established, which will propose or impose a solution or bring the parties together in order to facilitate an amicable solution. ${ }^{31}$

Given the cross-cutting scope of the ADR Directive, the question of the relationship with Directive on mediation arises.

Directive 2013/11 provides that the ADR Directive applies horizontally to all types of ADR procedures, including those covered by mediation Directive and that its provisions prevail in the event of a conflict over any other existing Union legal acts already containing provisions concerning out-of-court dispute resolution, however without prejudice to the mediation Directive (recital 19 and article 3, paragraph 2).

In addition to the above described regulatory actions, the Commission has also planned the creation of two European networks to facilitate consumer access to ADR procedures for cross-border disputes. Although they have the same purpose, their functioning differs greatly: the ECC-Net is a consumer information and assistance structure with contact points ("clearing houses") in each Member State, ${ }^{32}$ while the network for out-of-court settlement of cross-border financial services disputes (Fin-Net Financial Services Complaints Network) links national competent bodies which are required to comply with the requirements of the Recommendation 98/257/ EC. ${ }^{33}$

complaints were lodged, mainly in the clothing sector, air tickets and technological products. On the topic: EU Commission (2018b). "Grants for ADR entities, online traders and online marketplaces to upgrade the applicants' software to work with the ODR platform"; Cortes and Lodder (2014).

${ }^{31}$ The Directive only concerns disputes between consumers and traders, while the ODR Regulation also applies to disputes triggered by traders towards consumers, if the Member State allows the resolution of such disputes through an ADR entity. The Directive applies to disputes concerning contractual obligations arising from sales or service contracts both online and offline, whereas the regulation refers only to online contracts.

${ }^{32}$ The aim of ECC-Net is to provide consumers entering into cross-border disputes with information about their rights and obligations. A consumer will submit the claim to its national contact point; it will liaise with the contact point partner in the other MS to reach an amicable solution.

${ }^{33}$ On this subject: Commission "Fin-Net activity report 2016". Since 2001, the European Commission has promoted the creation of the Fin-Net among ADR entities active in the banking, financial and insurance sectors. 60 ADR entities are currently members of Fin.Net (EU, Iceland, Liechtenstein and Norway). The arrangements for the participants collaboration are covered by a Memorandum of Understanding, in force since 16 May 2016, that provides for network members, temporary members (for which recognition is pending), affiliated (ADR entities operating in countries where the Directive in not applicable, e.g. in Switzerland). 


\section{The Role of the IDD Directive Within the EU Legal Framework on ADR Procedures}

The IDD is the last step, in a chronological sense, of the European ADR legislative process described above ${ }^{34}:$ it therefore provides for the establishment of adequate out-of-court complaint and redress procedures for the settlement of disputes between customers and insurance distributors. It is one of those sector-specific provisions, with particular reference to the banking and financial sector, which require Member States to set up ADR systems and require intermediaries to provide information on their existence and on the activation of the procedure in order to protect the weakest part of the negotiating relationship. ${ }^{35}$

With the IDD and its delegated regulations, the European legislator finalised the second most important act aimed at modernising insurance supervision since the introduction, only a few years ago, of the new prudential supervision known as "Solvency II regime". 36

The strengthening of undertakings' capital adequacy is now followed by a redesign of the means for distributing insurance products. Both interventions have a unique and shareable intent: the construction of a market of more solid and robust undertakings, a more efficient distribution chain, better informed and protected consumers.

The IDD aims to strengthen and consolidate the existing rules of the Insurance Mediation Directive (IMD, Directive 2002/92). Where the IMD applied to the

\footnotetext{
${ }^{34}$ Directive 2016/97 of the European Parliament and of the Council of 20 January 2016 on insurance distribution. The IDD aims to strengthen and consolidate the existing rules of the Insurance Mediation Directive (IMD) introduced in early 2005 and designed to encourage competition between insurance firms, as well as ensure appropriate levels of protection for customers, across the EU. See Castle (2019), pp. 97-125; Hofmann et al. (2018), pp. 740-769; Pscheidl (2018), pp. 205-217; Maesschalck (2017), pp. 59-77; Christofilou (2016), pp. 267-298; Malinowska (2016), pp. 89-100; Bernardino (2015), p. 7.

${ }^{35}$ The obligation for MS to set up ADR systems in the field of banking and financial services derives from several provisions with an increasing degree of prescriptiveness: e.g. Directives 2002/65/EC (concerning the distance marketing of consumer financial services) and 2007/64/EC (on payment services, repealed by directive 2015/2366/EU), stated that Ms "shall promote the setting up or development of adequate and effective out-of-court complaints and redress procedures", while directive 2008/48/EC (on consumer credit agreements) provided for a formal obligation ("member States shall ensure that adequate and effective out-of-court complaint and redress procedures [...] are put in place"). Similar obligation can be found in Directive 2014/65/EU (on markets in financial instruments, article 75).

${ }^{36}$ The solvency II framework includes the Directive 2009/138/EC, the Delegated Regulation 2015/ 35/EU directly applicable in the MS, the (EIOPA) European Insurance Supervisory Authority's Guidelines, not binding third-level measures. Solvency II sets out a EU-wide set of capital and risk management requirements that match with the objective of consumer protection. The solvency assessment of an undertaking is based on the combination of three-pillar requirements, similar to Basel II for the banking sector: quantitative (capital requirements), qualitative (focused on the system of governance) and transparency. On the topic, see; Marano and Siri (2018), pp. 594-614; Marano and Siri (2017), cit; Swain and Swallow (2015), p. 145.
} 
regulation of insurance intermediaries, the IDD applies to the wider regulation of insurance 'distributors'. This means that it applies to all sellers of insurance products, including insurance undertakings that sell directly to customers; any person whose activities consist of assisting in the administration and performance of insurance contracts, including those acting on behalf of insurers-e.g., claims management activities; ancillary insurance intermediaries; websites or other media used to provide information about insurance contracts with comparison services, where the customer is able to directly or indirectly conclude an insurance contract. The directive is finalised to regulate the way insurance products are designed and sold both by insurance intermediaries and directly by insurance undertakings and ensure that consumers have the same level of protection regardless of the distribution channel.

For this purpose, IDD lays down the information that should be given to consumers before they sign an insurance contract; it imposes conduct of business and transparency rules on distributors, through provisions referring to the product design process on the basis of the target market (Product Oversight Governance) and the customer profiling (demand and need test).

With regard to ADR systems, Article 15 of IDD strengthens in the provisions of Article 11 of the IMD, by requiring Member States to establish (and not only to promote) adequate and effective out-of-court complaint and redress procedures for the resolution of disputes between insurance distributors and customers relating to the rights and obligations arising from the Directive. The provision is aimed to make the rules on transparency, conduct of business and consumer protection more effective and to avoid them becoming mere declarations of principle. ${ }^{37}$

\section{Issues About Implementing the ADR System in the Insurance Sector}

Many issues could arise from the implementation of Article 15 of the Directive in Member States. The generic formulation of the provision allows possible different configurations of the new system of out-of-court dispute settlement in the insurance sector, also having regard to the minimum harmonisation of the Directive 2013/11/ EU.

\footnotetext{
${ }^{37}$ In the sense of a strengthening of the consumer protection, referring to the impact of the EU regulation on financial products, mainly the rules laid down by MiFID II, to the insurance sector and more specifically with regard to life insurance, see Marano (2017).
} 


\subsection{The System's Setting}

First, the ADR system's setting up. In the extreme variety of the category and in the fundamental distinction between procedures based on an agreement of the parties and those centred on the decision of a third party, the reality of Ombudsmen could be particularly important. ${ }^{38}$ These bodies act in financial sectors (especially in the banking field), with a different degree of institutionalisation and coordination with the institutional objectives of the sectoral supervisory authorities. In the financial sector, the complementarity of ADR systems with supervisory authorities' objectives is marked, especially with regard to the links between disputes over the intermediary's misconduct and the supervision of conduct of business. The design of the ADR entity stemming from the IDD will be affected by its possible specific competence in the insurance sector or by the use of another out-of-court system already active in the banking and financial sector. ${ }^{39}$ It will be important for this entity if its staff is established within the sectoral supervisory authority: there could be problems in the coordination between the activity of the ADR body and the Authority; on the other hand, however, the Authority could be able to use the information deriving from the ADR activity for the purpose of supervising intermediaries. ${ }^{40}$

If there will be an out-of-court system centred on the decision of a third party, the choice could be made between a single or collegial body, with the need to guarantee the requirement of independence in both cases. This topic should be addressed on the basis of the ADR Directive, which provides that, when the decision is taken

\footnotetext{
${ }^{38}$ See Creutzfeldt (2016), Hodges (2014), pp. 593-608; Lener (2018). See also Schwarcz (2009), p. 735, that suggests that the British FOS (Financial Ombudsman Service) may offer a model for improving consumer dispute resolution in realms beyond insurance.

${ }^{39}$ At the beginning of 2017, a survey on the main characteristics of the members of Fin-Net was carried out upon the Italian Banking Supervisory Authority (Bank of Italy)'s initiative (see Italian Banking Ombudsman, Annual Report 2017, p. 44). The survey, which involved 48 ADR schemes from 27 member states, shows that Fin-Net members vary in the scope of their jurisdiction and in their procedures. For about half of the ADR schemes, their jurisdiction extends exclusively to disputes concerning only one financial sector (banking, investment or insurance services). Just over a third have jurisdiction over more than one sector. Only a few schemes also accept non-financial disputes. See also Cymand (2017), which shows that the currently existing ADR schemes in the area of financial services either cover financial services in particular sectors (i.e., Banking Ombudsman in Italy, Insurance Ombudsman in Germany, Ombudsman of the Authority of Financial Markets in France), all financial services sectors (Financial Ombudsman Service in United Kingdom, the Consumer Complaints Manager of the Malta Financial Services Authority, Financial Services Complaints Institute in Dutch) or handle consumer complaints in general (National Board for Consumer Complaints in Sweden, State Consumer Protection Authority in Lithuania).

${ }^{40}$ The survey previously described shows that in many cases the supervisory authorities for the purpose of supervising intermediaries use information obtained through the ADR scheme's activity. In some cases, the ADR entity report to the competent authority any conduct of intermediaries in breach of sectoral legislation. Sometimes, the ADR scheme is established within the supervisory authority. In other countries the data transmitted by ADRs are only statistical, as they don't include information concerning individual cases.
} 
individually, such subject must have the necessary competences and be appointed for a period of office of sufficient duration to ensure the independence of his actions, while if collegial, equal representation of consumers and market traders is to be respected. The latter consideration could involve important appraisals considering that in the insurance field there is a complex distribution system that sees both undertakings and intermediaries involved in the relationship with the customer. The involvement of both parties in distribution disputes is frequent. It could be relevant for the composition of the collegial body and for the number of members to be designated as representatives of undertakings and intermediaries.

\subsection{The Adherent Subjects}

From the point of view of market operators joining the system, they could be subject by law to the jurisdiction of the new IDD ADR or could join it on a voluntary basis and subject to certain conditions. ${ }^{41}$ In particular, the question of the adhesion of EU companies operating in another Member State could arise. The item is linked to the transnational nature of insurance disputes because of the large number of EU companies operating in different countries both under the freedom of establishment and under the freedom to provide services. For this reason, cross-border disputes in the insurance sector, in the sense of a dispute between a policyholder of a Member State and an insurance undertaking with head office in another Member State, might be very common. In this regard, article 15 of the IDD recommends that Member States shall ensure that European ADR bodies cooperate in the resolution of crossborder disputes. In the same direction, Directive 2013/11/EU provides that the handling of cross-border disputes shall be carried out through forms of cooperation between ADR entities and the strengthening of relevant European networks, including Fin-Net in which the new IDD ADR should also take part. The purpose of this network is therefore to provide consumers with easy access to ADR in cases regarding cross-border financial services: in other words, it enables consumers wishing to act against an intermediary in another Member State to ask to the ADR operating in their own State, that, through the network, will put the consumer in contact with the equivalent ADR system of the country in which the intermediary operates. A different line of thought could instead be based considering the supervision carried out by the host member state on transparency and fairness of behaviour and on compliance with the rules of general interest. That kind of supervision could request EU companies to adhere to the host ADR system. In the same direction, if the insurance contracts of these companies operating in another country provide that the law and jurisdiction of the State in which they operate shall apply,

\footnotetext{
${ }^{41}$ In the aforementioned survey of the Fin-Net ADR systems, almost two thirds of cases the intermediaries' participation in the system is mandatory; in certain cases adhesion may be mandatory or voluntary depending on the issue involved.
} 
the contract could be considered binding also for the adhesion to the ADR system of the host country.

\subsection{The Customers}

The meaning of "customer" should also be considered, since no definition can be found both in the IDD and in the ADR Directive. Although referring to the customer, the ADR Directive only defines the consumer as a natural person who acts for purposes different from entrepreneurial, commercial, or professional activity. It will therefore be necessary to consider whether the definition of customer will cover only the insured persons and the policyholder, as the persons who have or have had a contractual relationship $^{42}$ with an undertaking or an intermediary with regard to insurance services, or will have to include other subjects, such as persons who are entitled to receive insurance benefits or to claim compensation for the damage suffered (injured persons). The meaning of customer will depend on which disputes are handled with the IDD ADR system.

\subsection{The Nature of Disputes}

With regard to the nature of disputes, article 15 of the IDD refers to disputes between customers and insurance distributors concerning the rights and obligations arising under this Directive. The dispute could concern an action or omission relating to the activities of the insurance sector subject to regulation and supervision. The scope will depend on the national implementation of the provision: it could be limited to disputes arising from the violation of the rules of conduct inherent to insurance distribution (i.e. infringement of disclosure rules, a choice perhaps consistent with the wording of the Directive), or it could be extended to the determination of the rights and obligations deriving from an insurance contract (i.e. coverages, exclusions), to be evaluated whether to include the right to compensation for damage suffered. ${ }^{43}$ If the request were to concern the payment of a sum of money, it might be useful to provide for a limitation on the amounts. With regard to claiming damages, if they were included, it should be interesting to understand how the IDD ADR body could handle the evidence requirements: whether it could ask for external technical advice to ascertain the event or to quantify the damage suffered or could conduct

\footnotetext{
${ }^{42}$ It will be useful to understand whether the complainant is a customer or a potential customer and if the system covers both the contractual and the pre-contractual phases, with the protection of legitimate expectations.

${ }^{43}$ It will be interesting to evaluate if only financial loss or also pain and suffering, damage to reputation, distress or inconvenience.
} 
independent audits. It is a fact that the parties of the dispute should have to prove the circumstances that they use as the grounds for their request or explanations. If additional evidence or explanations are required, the ADR might request the parties to provide them. The decisions should be based upon the documents provided by the parties (complainant and intermediary) during the investigation. ${ }^{44}$

A time limit could also be envisaged, limiting the competence of the new ADR system to disputes arising within a limited time frame. This is in order to ensure the functionality of the new system, which would be undermined if decisions were to be taken on situations that are too far in the past. This would also help to speed up and streamline the ADR procedure, since it is more likely that questions would be resolved quickly if they refer to recent issues, for which documentation can be easily retrieved.

\subsection{The Procedure}

Concerning the procedure, the dispute should be free of charge to the claimant, ${ }^{45}$ while the financing of the system should be charged to the intermediaries subject to the IDD ADR jurisdiction. They should be required to contribute to it, with a fixed or variable fee related, for example, to the size of the intermediary or the number of claims filed against them.

Normally before submitting a dispute to the IDD ADR body, the customer should lodge a dispute with the insurance undertaking or intermediary, to solve the dispute directly, preserving the relationship of trust with the insurance operator. The ADR procedure should not be started too long after the complaint has been lodged. ${ }^{46}$

Finally, the ADR procedure could end in different ways, depending on the nature of the system adopted: if no agreement between the parties could be reached, the parties could be referred to the ordinary legal process, while in the event of a system

\footnotetext{
${ }^{44}$ In line with the speed of the procedure and the summary knowledge of out-of-court system. In this regard, recital 25 (directive 2013/11) provides that "In order to ensure that ADR entities can operate effectively, those entities should have the possibility of maintaining or introducing ... procedural rules that allow them to refuse to deal with disputes in specific circumstances, for example where a dispute is too complex and would therefore be better resolved in court."

${ }^{45}$ Under ADR directive, services must be provided at low or no costs to consumers. However, a nominal fee for consumers might encourage responsible use and adequate engagement with the dispute resolution process.

${ }^{46}$ In line with Directive 2013/11/UE, recital 50: In order to avoid an unnecessary burden being placed on ADR entities, Member States should encourage consumers to contact the trader in an effort to solve the problem bilaterally before submitting a complaint to an ADR entity. See also article 5, par. 4 lett. e): Member States may, at their discretion, permit ADR entities to maintain and introduce procedural rules that allow them to refuse to deal with a given dispute on the grounds that the consumer has not submitted the complaint to the ADR entity within a pre-specified time limit, which shall not be set at less than one year from the date upon which the consumer submitted the complaint to the trader.
} 
with a third party with decision-making powers, the question of the effectiveness of ADR decisions would arise. ${ }^{47}$ The decisions regarding the substance of the dispute could be a recommendation, not binding, not being appealed. In the case of a decision that totally or partly satisfies the consumer's request, it could establish the term within the insurance undertaking or intermediary is advised to take all actions pointed out. However, if the intermediary does not comply with a decision, its non-compliance would be made public. ${ }^{48}$ Such negative publicity could deter new customers from contacting the negligent undertaking or intermediary, indirectly inducing the latter to respect the ADR recommendations. ${ }^{49}$

\section{Closing Remarks}

The impetus provided by the European Union regarding ADR was decisive for the definition of the general principles in ADR systems. The different procedures that have been and will be implemented by Member States often reflect national legal traditions and the specific purpose of public supervision of the financial sector. However, ADR systems are growing strongly, both as a response to mistrust in the justice system and because they seem to be the most appropriate way to settle consumer disputes. ${ }^{50}$

\footnotetext{
${ }^{47}$ The ADR Directive acknowledges the competence of Member States to determine whether ADR entities established on their territories are to have the power to impose a solution (recital 4). See also Creutzfeldt and Bradford (2016): "in term of decision acceptance (..) people care, on average, more about the way a decision was reached than about its substantive content, and, moreover, that they are more likely to accept even unfavourable decisions if they feel they were reached in a procedurally fair way". The decision acceptance is strongly linked with the perception of fairness and impartiality of the procedure.

${ }^{48}$ See Green Paper on ADR in civil and commercial law, cit, 31: In the field of consumer protection law, the third party can be called upon to adopt a formal position on the solution to the dispute in the form of a decision which can be binding on a party. This is the case for clients' ombudsmen who were appointed by certain professional sectors such as banks and insurance companies and whose decisions are binding on the companies who are affiliated to the scheme. In this case, the effectiveness of the decision taken can essentially be measured in terms of marketing. If these professionals do not in fact comply with these decisions, they run the risk that this decision will be published, or if they are affiliated to a commercial system which, for example, awards quality labels, they may be excluded from this system.

${ }^{49}$ In the above-mentioned survey of Fin-Net ADR, it appears that in most of the schemes, the procedure ends with a recommendation or a non-binding decision, and the parties are free to bring the dispute before the courts. In some cases a financial intermediary's non-compliance with a decision is made public. However, one-third of the schemes have the authority to issue binding decisions which, in the event of non-compliance, may be enforced by the judicial authorities (e.g. if the decision is accepted by the client and if the value of the dispute does not exceed fixed thresholds).

${ }^{50}$ On 11 and 12 June 2018, the European Commission hosted the ADR Assembly 2018 which brought together representatives of notified European ADR entities (according to the Directive 2013/11/EU), ADR competent authorities, ODR contact points, European Consumer Centres,
} 
Through sectoral and cross-cutting legislative measures and networks, consumers will thus have appropriate tools to obtain effective and low-cost protection of their rights, particularly in the case of small claims, where the use of a judicial solution would be disproportionate. Considering the burden of insurance disputes on legal litigations, the establishment of an effective ADR system, faster and cheaper than ordinary judicial routes, should have important deflationary effects of judicial litigation and related costs, with potential positive and downside effects on the premiums charged to policyholders.

The financial education that could be carried out by IDD ADR towards the customer-consumer will be important, in order to spread the culture of awareness and the supervision and monitoring of the proper behaviour of undertakings and insurance intermediaries. This objective, together with the functioning of the new out-of-court resolution system, should strengthen the relationship of trust between insurance operators and customers and the reputation of the insurance sector, as well as reinforce consumer confidence in the financial system with a view to its soundness and stability.

The new IDD ADR system's decisions could have a dissuasive effect on similar breaches, and could lead insurance operators to modify certain practices found to be incorrect as sanctioned by the ADR system. In this sense, the educational function of such decisions could be fulfilled. ${ }^{51}$ The appeals submitted to the new system could also be used by insurance companies to monitor the adequacy of products to the target market's needs over time: the recurrence of similar requests could in fact reveal an inadequate profiling of the product for the target customers.

Time and the practical application of the new rules will show whether and how effective the new measures aimed to implement an ADR system in the insurance sector will be. Much will depend on the scope of the nature of the disputes that may be analysed by the IDD ADR system. The extent of the knowledge of the new ADR system among consumers will be equally important for the effectiveness of the new tool. ${ }^{52}$ However, the relative flexibility of the EU Member States in adopting more

consumer organisations, business associations and other stakeholders. Diversity in the ADR sector was seen by delegates to be positive both at individual level (diverse models may allow service users choose from a range of dispute resolution options) and at systemic level (competition in the sector can contribute to higher standards overall).

${ }^{51}$ In accordance with the accountability measures laid down in directive 2013/11/EU, article 7, par. 2, lett. b 2.: member States shall ensure that ADR entities make publicly available on their websites their annual activity reports, which shall include any systematic or significant problems that occur frequently and lead to disputes between consumers and traders; such information may be accompanied by recommendations as to how such problems can be avoided or resolved in future, in order to raise traders' standards and to facilitate the exchange of information and best practices.

${ }^{52}$ In line with the results of the 2018 ADR assembly previously mentioned, the need for a deep awareness and understanding appears as a fundamental also for the IDD ADR system, by publishing decisions, using social and traditional media and communication as a vital part of quality casehandling, educating and empowering consumers and ensuring transparency in the dispute resolution process. In fact, overlapping, geographical and sectoral competencies of ADR bodies may be confusing for service users and allow "forum shopping" by consumers. Differences in approach 
stringent rules - in respect of IDD previsions - may lead to a lack of uniformity and consistency. ${ }^{53}$ The jungle of competing systems with skills interlinked with other neighbouring sectors (financial, banking and insurance) may not help. For the time being, we can only hope that such an opportunity will not be lost and that the new out-of-court insurance dispute resolution instrument will effectively strengthen customer protection and the efficiency of the financial system.

\section{References}

ADR Assembly. https://www.europeanresolution.com/adr-assembly-2018-brussels-11-12-june/

BEIS (2018) Resolving consumer disputes: ADR and the court system. https://assets.publishing. service.gov.uk/government/uploads/system/uploads/attachment_data/file/698442/Final_ report_Resolving_consumer_disputes.pdf

Bernardino G (2015) Insurance distribution in a challenging environment. Speech at the European Federation of Insurance Intermediaries (BIPAR), Brussels, p 7. https://eiopa.europa.eu/

Biard A (2018) Monitoring consumer ADR in the EU: a critical perspective. Eur J Priv Law 2:171-196. academia.edu.documents/56294395

Biard A (2019) Impact of Directive 2013/11/EU on Consumer ADR quality: evidence from France and the UK. J Consum Policy 42:109-147. https://link.springer.com/article/10.1007/s10603018-9394-Z

Cappelletti M (1993) ADR processes within the framework of the world-wide access-to justice movement. Mod Law Rev 56:282-296. https://onlinelibrary.wiley.com/doi/pdf/10.1111/j.14682230.1993.tb02673.x

Castle H (2019) ADR and insurance-based investment products. In: Marano R (ed) Distribution of IBIPS. Springer, Cham, pp 97-125

Christofilou A (2016) ODR and insurance. In: Marano P, Rokas I, Kochenburger P (eds) The "Dematerialized" insurance. Springer, Cham, pp 267-298

Cortes P (2018) Consumer ADR in Spain and the UK. EuCML 2:82-88. http://academia.edu. documents/59203344

Cortes P, Lodder A (2014) Consumer dispute resolution goes online: reflection on the evolution of European law for out-of-court redress. Maastricht J Eur Comp law 15(1), SSRN-id2414098

Creutzfeldt N (2013) The origins and evolution of consumer dispute resolution systems in Europe. In: Hodges C, Stadler A (eds) Resolving mass disputes. https://ssrn.com/abstract=2441069

Creutzfeldt N (2016) What do we expect from an Ombudsman? Narratives of everyday engagement with the informal justice system in Germany and the United Kingdom. Int J Law Context 12 (4):437-452. https://doi.org/10.1017/S1744552316000203

Creutzfeldt N, Bradford B (2016) Dispute Resolution Outside of Courts: Procedural Justice and Decision Acceptance Among Users of Ombuds Services in the UK. https://onlinelibrary.wiley. com/doi/pdf/10.1111/lasr.12234

Crownie CH (2001) The ADR Act of 1998: implementing a new paradigm of justice. N Y Law Rev 76:1768. https://www.nyulawreview.org/wp-content/uploads/2018 /08/NYULawReview-76-6Crowne.pdf

between dispute resolution bodies might be a factor that contributes to poor public understanding of ADR.

${ }^{53}$ For further discussion in this direction, on the basis of a comparison with the Model Acts promulgated by the National Association of Insurance Commissioners (NAIC) in the United States, see Martinez and Marano (2020). 
Cymand D (2017) ADR Mechanism in the area of financial services in EU. Financ Law Rev 2. https://czasopisma.bg.ug.edu.pl/index.php/flr/article/view/2109

De Palo G, D'Urso L, Trevor M, Branon B, Canessa R, Cawyer B, Reagan L (2014) Rebooting' the Mediation Directive: Assessing the limited impact of its implementation and proposing measures to increase the number of mediations in the EU. http://www.europarl.europa.eu/ ReData/etudes/etudes/join/2014/493042/IPOL-JURI_ET\%2820 14\%29493042_EN.pdf

Della Noce DJ (2002) Mediation theory and policy: the legacy of the pound conference. Ohio State J Disp Resolut 17. https://kb.osu.edu/bitstream/handle/1811/87146/OSJDR_V17N3_545.pdf

ELI-ENCJ (European Network of Councils for the Judiciary) (2018) The relationship between formal and informal justice: The courts and ADR. www.europeanlawinstitute.eu/fileadmin/ user_upload/p_eli/Publications/ADR_Statement.pdf

EU Commission (2018a) Capacity-building grants for ADR entities. http://ec.europa.eu/research/ participants/portal/desktop/en/opportunities/cp/topics/cons-adr-2018.html

EU Commission (2018b) Grants for ADR entities, online traders and online marketplaces to upgrade the applicants' software to work with the ODR platform. https://ec.europa.eu/inea/en/ connecting-europe-facility/cef-telecom/apply-funding/2018-cef-te lecom-call-odr

European Court of Human Rights, Guide on Article 6. https://www.echr.coe.int/Documents/Guide_ Art_6_criminal_ENG.pdf

Gill C, Creutzfeldt N, Williams J, O’Neill S, Nial V (2017) Confusion, gaps and overlaps: a consumer perspective on ADR between consumer and businesses. www.citizensadvice.org. uk/Global/CitizensAdvice/Consumer\%20publications/Gaps\%20overlaps\%20consumer\% 20confusion\%20201704.pdf

Hodges C (2014) Consumer ombudsmen: better regulation and dispute resolution. ERA Forum, 15

Hofmann A, Neumann JK, Pooser D (2018) Plea for uniform regulation and challenges of implementing the new IDD. Geneva Pap Risk Insur 43:740-769

Italian Banking Ombudsman, Annual Report 2017. https://www.arbitrobancariofinanziario.it/abf/ relazioneannuale/index.html?com.dotmarketing.htmlpage.language $=3$

Kessler G, Finkelstein LJ (1988) The evolution of a multi-door courthouse. Cath U Law Rev 37:577. http://scholarship.law.edu/lawreview/vol37/iss $3 / 2$

Lener R (2018) The Securities and Financial Ombudsman. A brief comparison with the Banking and Financial Ombudsman. https://fchub.it/wp-content/uploads/2018/05/Lener-1.pdf

Loos M (2016) Consumer ADR after Implementation of the ADR Directive: Enforcing European Consumer Rights at the Detriment of European Consumer Law. https://papers.ssrn.com/sol3/ paperscfm?abstract_id $=2685651$

Maesschalck N (2017) The IDD: what does it change for Intermediaries and others. In: Marano P, Siri M (eds) Insurance regulation in the EU: solvency II and beyond. Palgrave Macmillan, pp 59-77. https://academia.edu.documents/58268329

Malinowska K (2016) Insurance transparency and protection regime under the IDD. Insur Rev 4:89-100. https://piu.org.pl/wp-content/uploads/2017/05/WU-2016-04-06-Malinowska-en.pdf

Marano P (2017) The 'Mifidization': the sunset of life insurance in the EU regulation on insurance?

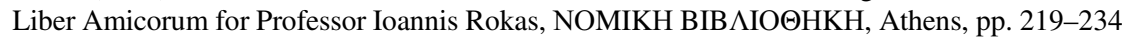

Marano P, Siri M (2017) Insurance regulation in the European Union: Solvency II and Beyond. Palgrave Macmillan. https://academia.edu.documents/58268329

Marano P, Siri M (2018) Cross-border insurance groups: towards a comprehensive supervision under Solvency II. Geneva Pap Risk Insur: Issues Pract 44:178

Martinez L, Marano P (2020) The new EU rules on insurance customer/policyholder protection viewed against the NAIC model acts. Global Jurist. https://doi.org/10.1515/gj-2019-0039

Menkel-Meadow CJ (2015) Mediation, Arbitration, and ADR. UC Irvine School of Law Research Paper No. 2015-59. https://ssrn.com/abstract $=2608140$

Pscheidl D (2018) Implementing IDD across the EU-first findings and the way forward. ERA Forum 19:205-217

Report from the Commission on the application of Directive 2013/11/EU, Brussels, COM(2019) 425 final, p. 1 
Report from the Commission on the implementation of the directive 2008/52/EC. http://www. europarl.europa.eu/doceo/document/A-8-2017-0238_IT.html

Sander F (1976) Address before the national conference on the causes of popular dissatisfaction with the Administration of justice: varieties of dispute processing. Fed Rules Decis 70

Schwarcz D (2009) Redesigning consumer dispute resolution: a case study of the British and American approaches to insurance claims conflict. Tul Law Rev 83:735. http://scholarship.law. umn.edu/faculty_articles/571

Sirena P (2018) ADR Systems in the Banking and Financial Markets. Osservatorio del diritto civile e commerciale, n. 2. https://www.rivisteweb.it/doi/10.4478/91897

Study on the use of ADR in the EU of 16 October 2009, pp 56-63; 112.115; 120-121. http://ec. europa.eu/consumers/redrescons/adrstudy.pdf

Swain R, Swallow D (2015) The prudential regulation of insurers under Solvency II, Bank of England. Q Bull Q2:145. http://www.bankofengland.co.uk/

Twining W (1993) Alternative to what? Theories of litigation, procedure and dispute settlement. In: Anglo-American Jurisprudence: some neglected classics. Mod Law Rev 56:380 e ss. https:// onlinelibrary.wiley.com/doi/pdf/10.1111/j.1468-2230.1993.tb02679.x

World Bank doing business 2019. https://www.doingbusiness.org/

\section{Legislation}

Green Paper Consumer access to justice and the settlement of consumer disputes within the single market, COM/93/576FINAL

Commission Recommendation 98/257/EC of 30 March 1998 on the principles applicable to the bodies responsible for out-of-court settlement of consumer disputes [1998] OJ L 115/31

Commission Recommendation 2001/310/EC of 4 April 2001 on the principles for out-of court bodies involved in the consensual resolution of consumer disputes [2001] OJ L 109/56

Communication from the Commission of 4 April 2001 on widening consumer access to ADR, COM (2001) 161

Green Paper on alternative dispute resolution in civil and commercial law, Brussels, 19.04.2002 COM (2002) 196 final

Directive 2008/52/EC of the European Parliament and of the Council of 21st May 2008 on certain aspects of mediation in civil and commercial matters

Directive 2009/138/EC of the European Parliament and of the Council of 25 November 2009 on the taking-up and pursuit of the business of Insurance and Reinsurance (Solvency II) (Official Journal of the European Union L 335/1)

Directive 2013/11/EU of the European Parliament and of the Council of 21 May 2013 on alternative dispute resolution for consumer disputes

Regulation (EU) n. 524/2013 of the European Parliament of the Council of 21 May 2013 on online dispute resolution for consumer disputes (Regulation on consumer ODR)

Directive 2016/97 of the European Parliament and of the Council of 20 January 2016 on insurance distribution (Official Journal of the European Union L 26/19)

Legislative decree report on the IDD implementation in Italy, 2018., http://documenti.camera.it/ apps/nuovosito/attigoverno/Schedalavori/getTesto.ashx?file=0516_F001.pdf\& leg $=$ XVII \#pagemode $=$ none 
Open Access This chapter is licensed under the terms of the Creative Commons Attribution 4.0 International License (http://creativecommons.org/licenses/by/4.0/), which permits use, sharing, adaptation, distribution and reproduction in any medium or format, as long as you give appropriate credit to the original author(s) and the source, provide a link to the Creative Commons licence and indicate if changes were made.

The images or other third party material in this chapter are included in the chapter's Creative Commons licence, unless indicated otherwise in a credit line to the material. If material is not included in the chapter's Creative Commons licence and your intended use is not permitted by statutory regulation or exceeds the permitted use, you will need to obtain permission directly from the copyright holder. 